\title{
Remote sensing and GIS-based forest fire risk zone mapping: The case of Manisa, Turkey
}

\author{
Derya Gülçina," (iD, Bülent Deniz ${ }^{\mathrm{a}}$ (i)
}

\begin{abstract}
The aim of this research is to map the potential forest fire risk zones using various landscape analysis techniques in Manisa province, Turkey. Forest fire, which is defined as an ecological disaster caused by natural processes or as a result of human activities, causes environmental degradation and fragmentation of the landscape. Therefore, it is very important to produce a fire risk zone map that can be used to minimize the frequency of fire, to prevent damage, to provide a prediction for the problems that may cause fire and to form a decision mechanism for the solution methods. This research utilized CORINE 2018 produced under the framework of the Copernicus Program which is the European Union's Earth Observation Programme coordinated and managed by the European Commission, ASTER Global DEM digital elevation model data obtained from the website of NASA Earthdata, fire archive records based on MODIS satellite images, digital stand map displaying the spatial distribution of tree species, and the OpenStreetMap (OSM) which were used for mapping the existing road network. Vegetation cover, slope, aspect, elevation, distance to settlement, and distance to road variables were used to determine risk zones. The specific weights were assigned to each thematic map layer according to their capacity on fire ignition. The slope, aspect, and elevation maps were generated from the digital elevation model. The distance to settlement map was generated from the CORINE database while the distance to road map was produced from OSM. The Fire Risk Zone Index (FRZI) was utilized to determine forest fire risk zones. According to the generated final fire risk map, almost $25.8 \%$ of the study area was predicted to be under very high and highrisk zones. The final forest fire risk model was validated with past fire incidents data that was acquired from MODIS images as fire points. The result of this research showed that out of 149 fire incidents in Manisa between 2001 and 2018 , 97 incidents had occurred in very high and highrisk areas. This finding supports that the presented methodology based on RS and GIS techniques is reliable and can be effectively used in the process of delineation of the forest fire risk zones.

Keywords: Forest fire, Risk mapping, Ignition, GIS, Manisa
\end{abstract}

\section{Uzaktan algılama ve CBS yöntemleri ile orman yangını risk alanlarının haritalanması: Manisa örneği}

\begin{abstract}
Özet: $\mathrm{Bu}$ araştırmanın amacı, çeşitli peyzaj analiz tekniklerini kullanarak Manisa ilindeki potansiyel orman yangın risk bölgelerini haritalamaktır. Doğal olarak veya insan faaliyetlerinin sonucunda ortaya çıkan orman yangını, ekolojik bağlantılılığın azalmasına ve peyzajın parçalanmasına neden olur. Bu nedenle, yangın sıklığını en aza indirmek, hasarı önlemek, yangına neden olabilecek sorunlara yönelik tahmin yapmak ve çözüm yöntemlerinde karar mekanizması olarak kullanılabilecek yangın risk bölgesi haritasından yararlanılmaktadır. Bu araştırmanın materyalini, Avrupa Birliği tarafından koordine edilen ve yönetilen Yer Gözlem Programı olan Copernicus Programı çerçevesinde üretilen CORINE 2018 verisi, NASA Earthdata web sitesinden elde edilen ASTER Global DEM sayısal yükseklik modeli verisi, MODIS uydu görüntülerine dayanan yangın arşiv kayıtları, ağaç türlerinin mekânsal dağılımını gösteren sayısal meşcere haritası ve mevcut yol ağını haritalamak için kullanılan OpenStreetMap (OSM) verileri oluşturmaktadır. Risk bölgelerini tanımlamak için bitki örtüsü, eğim, bakı, yükseklik, yerleşim yerine ve yola uzaklık değişkenleri kullanılmıştır. Orman yangını çıkma potansiyeline göre her bir tematik harita katmanındaki öznitelik değerlerine belirli ağırlıklar atanmıştır. Sayısal yükseklik modelinden eğim, bakı ve yükseklik haritaları oluşturulmuştur. Yerleşim haritasına olan mesafe CORINE veri tabanından, yol haritasına olan mesafe ise OSM'den üretilmiştir. Orman yangın riski bölgelerini belirlemek için Yangın Riski Bölge Endeksi kullanılmıştır. Oluşturulan yangın riski haritasına göre, çalışma alanının \%25.8'inin çok yüksek ve yüksek seviyede yangın riski taşıdığı ortaya çıkmıştır. MODIS görüntülerinden elde edilen 2001 ve 2018 yılları arasındaki orman yangını verileri ile yüksek ve çok yüksek yangın riski taşıyan alanlar çakıştırılmış, 149 orman yangının 97'sinin yüksek ve çok yüksek risk altındaki alanlarda meydana geldiği ortaya çıkmıştır. Bu bulgu, uzaktan algılama ve CBS tekniklerine dayanan metodolojinin güvenilir olduğunu ve orman yangın riski bölgelerinin tanımlanma sürecinde etkin bir şekilde kullanılabileceğini desteklemektedir.
\end{abstract}

Anahtar kelimeler: Orman yangını, Risk haritalama, Tutuşma, CBS, Manisa

\section{Introduction}

Environmental processes have led to the need to plan and manage natural resources at a landscape scale. For example, the likelihood of a forest fire depends on the basic factors such as composition, spatial distribution, season, elevation and aspect that the fire-sensitive plant species form in the environmental process. However, in most cases, planning at the landscape scale is difficult because administrative boundaries established by society do not

\footnotetext{
$凶 \quad$ a Aydın Adnan Menderes Üniversitesi, Ziraat Fakültesi, Peyzaj Mimarlığı Bölümü, Aydın

@ * Corresponding author (İletişim yazarı): derya.gulcin@ubc.ca

$\checkmark \quad$ Received (Geliş tarihi): 22.11.2019, Accepted (Kabul tarihi): 10.03.2020
}

Citation (Atıf): Gülçin, D., Deniz, B., 2020. Remote sensing and GIS-based forest fire risk zone mapping: The case of Manisa, Turkey. Turkish Journal of Forestry, 21(1): 15-24. DOI: $10.18182 /$ tjf.649747 
conform to ecological boundaries. Therefore, organizations, institutions and researchers around the world have been working to improve natural resource management (Fischer et al., 2016). Forests are an important part of the natural landscape and play an important role in maintaining environmental balance (Jaiswal et al., 2002). Forest fires are complex events that occur as a result of natural processes and/or human activities. Forest fires cause extinction of many living beings and long-term or permanent damage to habitats and threaten biodiversity. In addition, forest fire is a phenomenon that brings about loss of income in relation to forest products, damage to agricultural areas and economic and cultural destruction. In addition, some areas exposed to fire are opened to construction and lead to irreversible landuse changes. Today, forest fires are among the frequently discussed environmental issues in Turkey. According to the statistical data published by the General Directorate of Forestry in the last 29 years from 1988 to 2017, it is seen that the total number of fires is 61.313 and the total amount of burned area is 307.855 hectares (GDF, 2017). When the causes of forest fires in the last 20 years were examined, $58.7 \%$ were found to be human-caused, $33.2 \%$ stemming from negligence, $1.4 \%$ from natural causes and $6.4 \%$ were unidentified (GDF, 2017).

It is possible to identify forest fire risk areas in order to minimize the frequency of fire and prevent damage (Chuvieco and Congalton, 1989; Adab et al., 2013). It is necessary to create a fire risk area map in order to predict the problems that may cause fire and take decisions regarding the solution methods (Tian et al., 2013). Effective management of forest fires depends on reducing the risk of fire, restoration of fire regimes and appropriate planning for maintenance (Keifer et al., 2000). In general, forest fire management consists of four stages: mapping potential fire danger and risk, identifying hot spots, monitoring active fires and evaluating post-fire deterioration (Roy, 2003). Determining the risk of fire is the most important step because predicting the area with the highest risk minimizes the fire threat (Yang et al., 2007).

Remote Sensing (RS) and Geographic Information Systems (GIS) allow qualitative and quantitative analysis of forests and other ecosystems on spatial scales (Sowmya and Somashekar, 2010; Ghobadi et al., 2012; Guney et al., 2016). In addition, both methods are used effectively in the investigation, monitoring, and identification of forest fires. Various studies have used different methods to develop forest fire risk maps that correlate environmental factors of a region with the potential of forest fires, thus focusing on the effects of environmental factors on the occurrence of forest fires and the mapping of risk potentials (Chou et al., 1993; Díaz-Delgado et al., 2004; Renard et al., 2012). Forest fire risk zone maps are based on the classification of the relative sensitivity of forest areas to a forest fire in a region (Hacisalihoglu, 2018). While creating these maps, natural and man-made factors that lead to fire are investigated (Karabulut et al., 2013; Gungoroglu, 2017). While determining the factors, the factors that caused the past forest fires in the research area are examined and the potential areas of future fires are determined. In other words, forest fires that occurred in the past serve as a guide for the prevention, planning and decision-making of possible future fires (Duran, 2014).

Risk zone in forest fire susceptibility studies classify sensitivity to fire as "very low", "low", "medium", "high" and "very high". A review of the literature related to the variables that cause forest fire reveals that fire is caused by the combination of many spatial variables such as altitude, slope, aspect, distance to road and settlement (Coban and Eker, 2010; Nuthammachot and Stratoulias, 2019). In India, one of the researches aimed to model fire risk zones with GIS and RS methods. As a variable in risk analysis, proximity to the road and settlements, slope, aspect and topographic index were used. They divided the risk probability into 4 classes and stated that $30 \%$ of the study area is high and very high-risk areas (Jaiswal et al., 2002). Catry et al. (2010) observed that the majority of fires started in agricultural and rural areas and that the fire occurred in areas close to the road in Portugal. As a result of this study, the most effective factors for ignition were determined to be population density, distance to roads and elevation. In another study conducted by Gugliette et al. (2011), it was found that forest areas with a high probability of fire (risk of ignition) are close to residential areas where there is intensive human activity and roads, which are densely used. Malik et al. (2013) used slope, aspect, elevation, distance to road, distance to settlement area and land cover types to determine forest fire risk zones.

GIS-based methods and statistical and probability-based methods are used in the production and analysis of forest fire susceptibility maps that need to be evaluated together with topographic factors and many natural and man-made parameters (Coban and Erdin, 2020). In order to produce forest fire susceptibility maps, methods such as artificial neural networks based on various algorithms, support vector machines and decision tree method, logistic regression method based on statistical methods, probability-based frequency ratio have been proposed in recent years (Dong et al., 2005; Martínez-Fernández et al., 2013; Gungoroglu, 2017; Abedi Gheshlaghi et al., 2019; Nuthammachot and Stratoulias, 2019). GIS-based Multi-Criteria Decision Analysis (MCDA) method is one of the methods preferred and developed to map forest fire risk by many researchers in the literature (Dong et al., 2005). GIS provides great convenience in the evaluation of numerous geographical parameters with variable values and in the analysis of events and phenomena, which develop under the control of these geographical parameters (Malczewski, 1999; Jaiswal et al., 2002; Karabulut et al., 2013).

The aim of this research was to create a forest fire risk zone map for the study site using the MCDA method. By investigating fires and environmental factors in Manisa province, this study adds to the understanding of fire emergence. Ultimately, these data will form the basis for the preparation of strategic action plans to prevent fires before they break out. The research focuses on two main objectives: (I) Plotting the risk map with the fire points obtained from MODIS-based images between the years 2000-2018, (II) Validating the forest fire risk zone model used, by utilizing the previous fire points. 


\section{Materials and methods}

\subsection{Material}

The research area was defined as the province of Manisa, which was surrounded by cities named Uşak and Kütahya in the west, İzmir, Aydin, and Denizli in the south, and Balıkesir in the north (Figure 1). Manisa has $13.810 \mathrm{~km}^{2}$ surface area. According to the CORINE map, $29 \%$ of its surface area is covered with forests and $53 \%$ with agricultural areas. Manisa has both cultural and natural landscape features such as Spil Mountain National Park and Mesir Nature Park, Sureyya Nature Park and Kula Fairy Chimneys Natural Monument. There are various ecosystems within the provincial borders, including sensitive ecosystems. In addition, there are habitats that are critical to wildlife. Since 2001, a total of 149 forest fires have occurred in the province. The region has valuable forest areas, ecosystem diversity and rich wildlife habitat areas. The Mediterranean climate is the dominant climate in the area in general for most of Manisa province. In the plains and valleys surrounding the plains, a continental Mediterranean climate is observed, while in the high mountainous regions and plateaus, the effects of the Central Anatolia continental climate are seen (MOM, 2019).

The datasets analyzed consisted of 2018 CORINE map obtained from the European Environment Agency's Land Cover Program inventory database, ASTER Global DEM digital elevation model data obtained freely from NASA Earthdata website, fire archive records based on MODIS satellite images, digital stand map showing the spatial distribution of vegetation and OpenStreetMap (OSM) data.

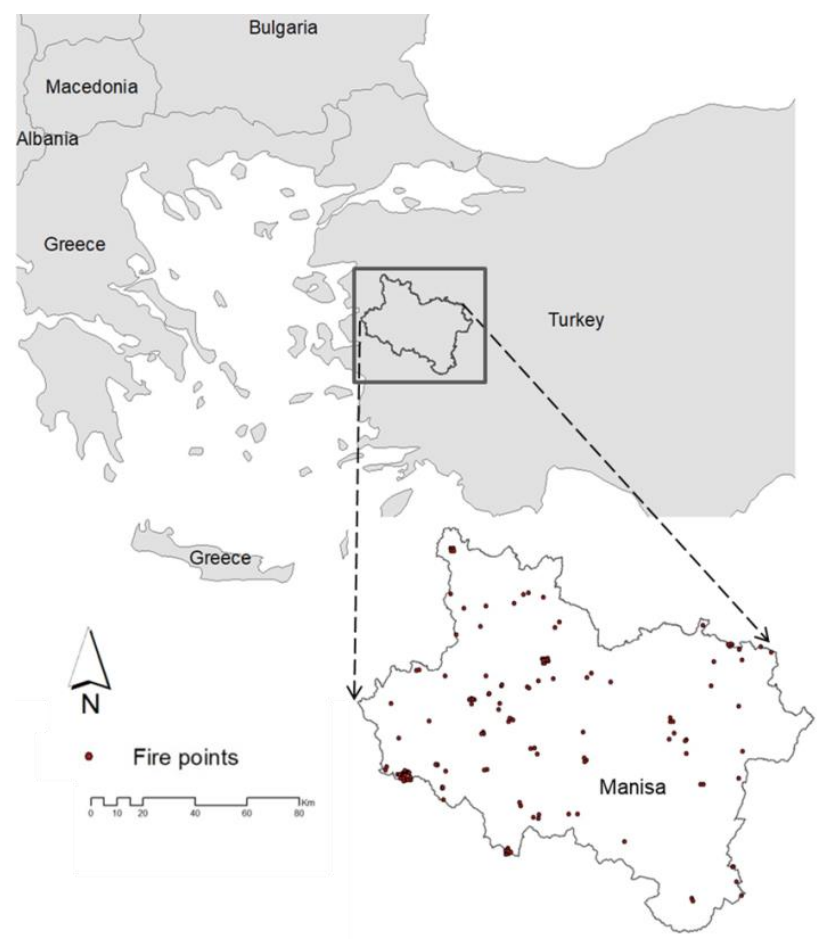

Figure 1. Research area

\subsection{Methods}

The first step of the method consisted of gathering, extracting, and producing the necessary data sets of the research area. The slope, aspect and elevation maps are produced based on the numerical elevation model; distance from settlement map is produced based on the CORINE database, and distance from the road map is produced based on OSM. As a result of the calculations done by various methods to do forest fire sensitivity analyses, weights are determined on the basis of the data layer. The parameter which has the greatest effect on forest fire sensitivity was given the highest weight value. The main objective of the analysis is to determine the property of the same pixel from each layer and its mathematical value and effect on the production of forest fire susceptibility map. Each thematic layer is evaluated according to the effect of forest fire and index maps are produced. In order to produce the result map, the pixel factor points (weight values) corresponding to the sub-criteria of each layer are assigned to the pixels to which they belong, and the determined weight values of the layers are multiplied by pixel factor points. The pixel values in the forest fire susceptibility map generated as a result of these operations are divided based on usage and sensitivity is classified as very high, high, medium, low and very low. Percentage and area distributions of sensitivity zones in the study area are determined as a result of the analyses. The forest fire inventory map showing the starting points of the forest fires is overlapped with the forest fire susceptibility map and the distribution of the existing forest fires according to the susceptibility zones is determined (Figure 2).

1. All parameters are assigned a risk factor according to the potential for fire risk. Here, the most favourable condition for fire is expressed with the number " 4 " (very risky) and the least favourable or unfavourable condition is expressed with the number " 0 " (risk-free) (Table 1). The function score (FS) of each criterion was calculated using the formula (1) below (Pradhan et al., 2007). In this formula, $\mathrm{Cr}$ shows the criterion, and $\mathrm{f}$ shows the function value.

$F S=C r_{1} f_{1}+C r_{2} f_{2}+\cdots+C r_{n} f_{n}$

2. Fire Risk Zone Index (FRZI) was calculated using the risk factor score assigned data and taking the weighted scores used in the studies conducted by Chuvieco and Congalton (1989), Jaiswal et al. (2002), and Malik et al. (2013) as reference. The following equation (2) is proposed for the 6 criteria used in FRZI calculation. According to this formula, multiplying the function score by the weight value constitutes the index value. In this equation, "W" represents the weight value and "FS" represents the function score.

$F R Z I=W_{1} F S_{1}+W_{2} F S_{2}+W_{3} F S_{3}+W_{4} F S_{4}+W_{5} F S_{5}+W_{6} F S_{6}$ 


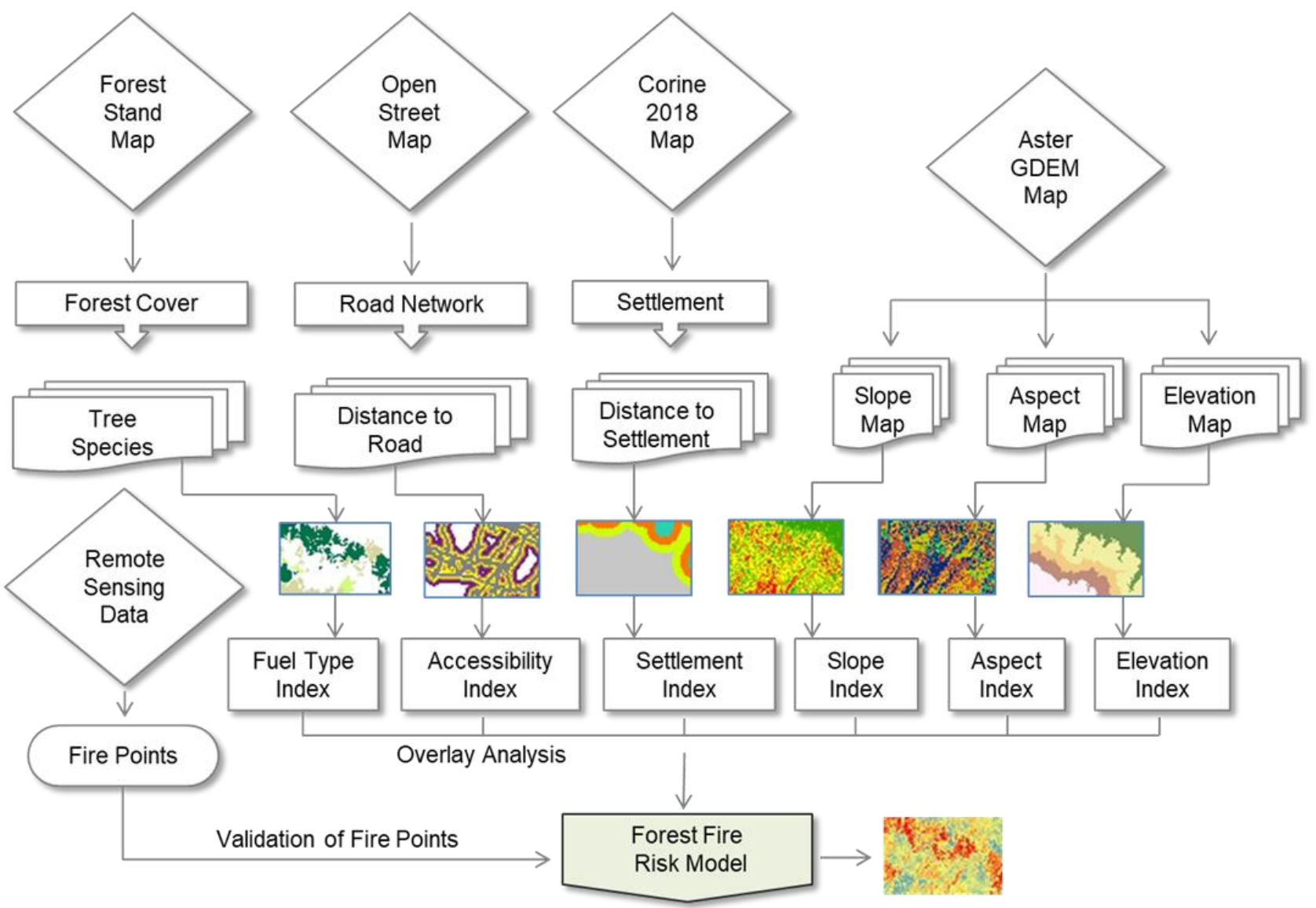

Figure 2. Research methodology

Table 1. Weights and ratings assigned to variables and risk classes (Chuvieco and Congalton, 1989; Jaiswal et al., 2002; Malik et al., 2013; Bingol, 2017)

\begin{tabular}{|c|c|c|c|}
\hline Variable (weight) & Class & Rating & Risk class \\
\hline \multirow{5}{*}{ Vegetation (9) } & Very dry & 4 & High risk \\
\hline & Dry & 3 & Risky \\
\hline & Moderately moist & 2 & Moderate risk \\
\hline & Moist & 1 & Low risk \\
\hline & High moist & 0 & Risk free \\
\hline \multirow{5}{*}{ Elevation (4) } & $0-250 \mathrm{~m}$ & 4 & High risk \\
\hline & $250-500 \mathrm{~m}$ & 3 & Risky \\
\hline & $500-750 \mathrm{~m}$ & 2 & Moderate risk \\
\hline & $750-1000 \mathrm{~m}$ & 1 & Low risk \\
\hline & $1000-2070 \mathrm{~m}$ & 0 & Risk free \\
\hline \multirow{5}{*}{ Slope (\%) (8) } & $0-5$ & 4 & High risk \\
\hline & $5-10$ & 3 & Risky \\
\hline & $10-20$ & 2 & Moderate risk \\
\hline & $20-30$ & 1 & Low risk \\
\hline & $>30$ & 0 & Risk free \\
\hline \multirow{5}{*}{ Aspect (7) } & South & 4 & High risk \\
\hline & West & 3 & Risky \\
\hline & East & 2 & Moderate risk \\
\hline & North & 1 & Low risk \\
\hline & Flat & 0 & Risk free \\
\hline \multirow{4}{*}{$\begin{array}{l}\text { Distance to settlement } \\
\text { (5) }\end{array}$} & $0-1000 \mathrm{~m}$ & 4 & High risk \\
\hline & $1000-2000 \mathrm{~m}$ & 3 & Risky \\
\hline & $2000-3000 \mathrm{~m}$ & 3 & Moderate risk \\
\hline & $>3000$ & 1 & Low risk \\
\hline \multirow{5}{*}{$\begin{array}{l}\text { Distance to road } \\
\text { (6) }\end{array}$} & $0-200 \mathrm{~m}$ & 4 & High risk \\
\hline & $200-400 \mathrm{~m}$ & 3 & Risky \\
\hline & $400-600 \mathrm{~m}$ & 2 & Moderate risk \\
\hline & $600-800 \mathrm{~m}$ & 1 & Low risk \\
\hline & $800-1000 \mathrm{~m}$ & 0 & Risk free \\
\hline
\end{tabular}

In the production of the risk zone map, environmental factors such as vegetation, elevation, slope, aspect, distance to settlement and distance to road were utilized. The degree of fire risk was determined with the help of conditional inquiries and overlay analysis in GIS environment. The forest fire risk map produced as a result of the research was divided into five sensitivity classes.

\subsubsection{Findings Aimed at the Evaluation of Risk Factors}

\subsubsection{Vegetation}

Due to the characteristics of the geography, the province shows differences in terms of soil, geological and morphological structure and climatic conditions in the westeast direction. This difference has caused changes in vegetation composition. This vegetation differentiation in the west-east direction is regular and certain. The fact that the mountain masses cut off the sea effect that the Mediterranean climate and the continental climate prevail in some places lead to the coexistence of plant species grown in different climatic conditions. Depending on the elevation, scrub, drought-resistant forests with evergreen trees in the Mediterranean vegetation are generally found aggregately at heights above $150 \mathrm{~m}$. oak (Quercus spp.), red pine (Pinus brutia Ten.), and black pine (Pinus nigra Arnold.) are common forest trees (MPCTD, 2019). According to the numerical stand map of the research area, dominant tree species were examined and when forming vegetation map, 
mixed stand areas were included in dominant species areas. Sixty percent of forests were observed to be composed of red pine ( $P$. brutia Ten.), 24\% of them, of the afforestation area called forest soil, 9\% of oak (Quercus spp.), $4 \%$ of black pine (P. nigra Arnold.), $2 \%$ of stone pine (Pinus pinea L.), and $1 \%$ of juniper (Juniperus spp.). The tree species whose distribution is very limited are cedar (Cedrus spp.), chestnut (Castanea sativa Mill.), and cypress (Cupressus sempervirens L.). Vegetation is one of the most important factors determining the starting point of forest fires and fire behavior. Different plant species also have different combustion characteristics (Akkas et al., 2008; Karabulut et al., 2013). While species such as red pine, which are coniferous trees with dry character, form the appropriate conditions for fire, it was stressed that cypress $(C$. Sempervirens L.) may be the most effective tool for fire prevention (Neyisci, 1987; Karabulut, 2013). In this context, plant species in the Manisa forest area were classified according to their moisture level. Red pine (P. brutia Ten.), black pine ( $P$. nigra Arnold.) and stone pine ( $P$. pinea L.) were evaluated in the group "very dry"; cedar (Cedrus spp.) was evaluated in the group "dry"; oak (Quercus spp.) "moderately moist"; juniper (Juniperus spp.) "moist"; chestnut (C. sativa Mill.), and cypress (C. sempervirens L.) in the "high moist" group (Figure 3).

\subsubsection{Topography}

The topography is a determinant physiographical factor regarding forest fire (Jaiswal et al., 2002). The elevation of the research area varies between 9-2070 m. Manisa city center, which is in Gediz depression, is $71 \mathrm{~m}$ high. Towards the northeast, the elevation increases, and the district center reaches the elevation of $850 \mathrm{~m}$. in Demirci. The important mountains of the province are Bozdağlar (Kumpınar 2070 $\mathrm{m}$ ), which is also the highest mountain of the region, Spil (Karatepe $1517 \mathrm{~m}$ ), on the slopes of which the city center is settled and Yunt Mountain (Nemrut Tepe 1074 m). Demirci Mountains also form the boundaries of the provinces Manisa, Kütahya and Balıkesir and its highest point Ziyaret Tepe $(1800 \mathrm{~m})$. The highest point of Çomaklı and Dibek Mountains, which are the southwest extension of the Demirci Mountains, Aysekizi Hill is $1034 \mathrm{~m}$. The Uysal Mountain, which runs parallel to Alaşehir Stream also has a elevation of $1135 \mathrm{~m}$ (MOM, 2019). The mountainous and steep areas are located in the east, south and north of the province: the mountains whose altitude decreases towards the west are cut by creeks and streams. The eastern parts of Manisa are located on a southeast-northwest axis threshold between the wide bowl of Central Anatolia which is farther in the east and the Gediz and Kumçayı plains in the Aegean region. Bozdağlar, which is in the south of the province, descends to the north, that is, on the Gediz valley, quite steeply. In Manisa, all forms of landforms can be found. $54.3 \%$ of the province's surface area is composed of mountains and $27.8 \%$ plateaus (MPCTD, 2019). The risk of forest fire is inversely proportional to elevation. The elevation map is formed by the classification of the numerical elevation model. The $0-250 \mathrm{~m}$ range is considered to be very risky and the areas higher than $1000 \mathrm{~m}$ are evaluated in the risk-free group. The slope is one of the topographic features effective in the formation and spread of forest fires. Aspect is also an effective factor in the spread of forest fire. The rate of a sensation of the sun effect on the south-facing slopes due to the aspect of the topography is more dominant than that of the north (Lin and Sergio, 2009; Malik et al., 2013). The numerical elevation model was also utilized in forming the slope map and \% value was considered in the classification of the slope groups. In this context, while $0-5 \%$ slope is considered to be very risky in terms of forest fire, areas with a slope greater than $30 \%$ are evaluated in risk-free class. In the aspect map, the southern slopes are assigned to the riskiest class. The factor value of flat areas in terms of fire risk was accepted as " 0 ".

\subsubsection{Distance to settlement}

Within the boundaries of the research area, there are 17 districts, 1088 neighbourhoods and many residential areas connected to these neighbourhoods (MOI, 2019). The parts of the forests that are close to the settlements are the areas where a fire is more likely. Human activities pose a high risk of fires caused by accidents or neglect. Therefore, distance from settlement has also been defined as an effective factor in forest fire susceptibility analyses (Jaiswal et al., 2002; Joaquim et al., 2007). Although the risk level decreases as we move away from settlements, today, the spread of human activities on large areas also causes the risk areas to spread on a wide area (Karabulut et al., 2013). The thematic layer of the settlements in the research area was produced from the urban fabric in the artificial areas in CORINE map of 2018 provided by the European Environment Agency's Land Cover Program inventory database. The distance from the settlement area was evaluated in four groups. The distance of $0-1000 \mathrm{~m}$ is decisive in terms of forest fire risk. Areas in a distance higher than $3000 \mathrm{~m}$ are evaluated in the low-risk class.

\subsubsection{Distance to road}

Roads account for the large basis for the cause of manmade fires due to the constant movement of people and vehicles. The parts of forests close to the road are defined as areas with high fire sensitivity (Cardille and Ventura, 2001; Catry et al., 2010). The road network map of the research area was obtained from the OSM database. The path data downloaded with OSM extension was converted to shapefile vector data in QGIS program. Distance to road was evaluated in 5 classes being 0-200, 200-400, 400-600, 600800 , and 800-1000 $\mathrm{m}$.

\section{Results and discussion}

\subsection{The output of thematic maps}

Distance from the thematic maps to the road, distance from the settlement data, vector, thematic maps of other criteria are in raster format. The conversion of vector data to raster data was performed using the conversion tool in ArcMap 10.5 software and all the thematic maps were prepared with a resolution of $10 \mathrm{~m}$ (Figure 3). 

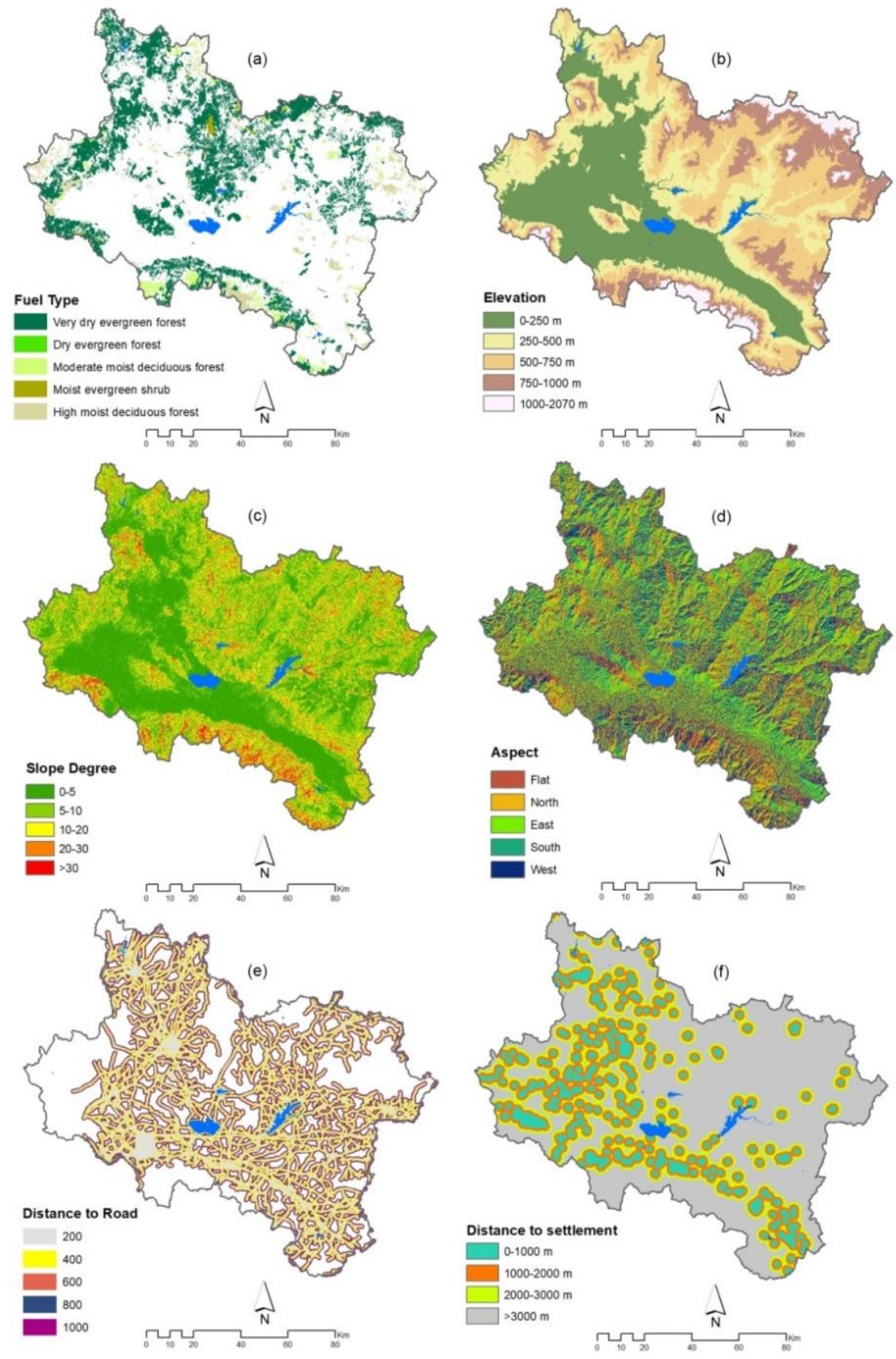

Figure 3. The individual input layers of (a) fuel type, (b) elevation, (c) slope, (d) aspect, (e) distance from road, and (f) distance from settlement

\subsection{Fire risk zone mapping}

Data affecting the formation and behavior of fire are important in combating forest fires. In this research, the fire risk map related to these factors was put forth by analysing the topography (slope, aspect, and elevation), vegetation, distance to road and settlement area of Manisa province. According to the FRZI formula (3), the equation that contains the weight scores of the criteria used in the research is as follows (Malik et al., 2013):

$F R Z I=9 F_{i}+8 S L_{i}+7 A_{i}+6 R_{i}+5 S_{i}+4 E_{i}$
Based on the principle of weighted sum, this index is designed as a model assigning each parameter a weighting coefficient based on its influence on the spread of fire (Belgherbi, 2018). $F_{i}$, indicates the combustion index and shows the burning potential of the vegetation according to the moisture condition. Since its effect on forest fire is maximum, "9" was assigned a weight value. The second highest weights were respectively index of slope $\left(S L_{i}\right)$ and index of aspect $\left(A_{i}\right)$. Because the directions facing the sun receive direct sunlight and render the fuel drier and flammable. Distance from road index $(R)_{i}$ was assigned "6" as the weight value, and distance from settlements index $\left(S_{i}\right)$ was assigned "5" as the weight value. The weight value of the elevation index was determined to be " 4 ". When the 
fire risk zone map of Manisa is examined, it is seen that especially the vegetation and settlement areas have a high impact on the formation of areas with fire potential (Figure 4).

When examined in terms of vegetation, it appeared that red pine (Pinus brutia Ten.) is generally spread about risky areas. In terms of settlement areas, it is observed that the forests around Manisa settlement centers are in very highrisk and high-risk class in terms of fire. Through the overlay analysis, the forest fire risk map produced was divided into five sensitivity classes. It was found that $8.4 \%$ of the research area had very high, $17.4 \%$ had high, $24.7 \%$ had moderate, $30.3 \%$ had low and $19.2 \%$ had very low levels of forest fire risk. As the Fire Risk Zone Value Index value, 35-60 range expresses very low, 60-77 range low, the 77-93 range medium, the 93-113 range high, and 113-171 range very high risk. The amount of space occupied by fire risk groups is presented in Figure 5 as a bar and a pie chart. According to the data visualization in Figure 5, while the risk groups occupying the largest space are low and medium level, the risk groups that occupy the least space consist of areas with very high and very low-risk levels. This is followed by the intermediate-risk group and the lowest risk group, respectively. The pie chart provides a better visualization choice and illustrates the percentages of risk zones.
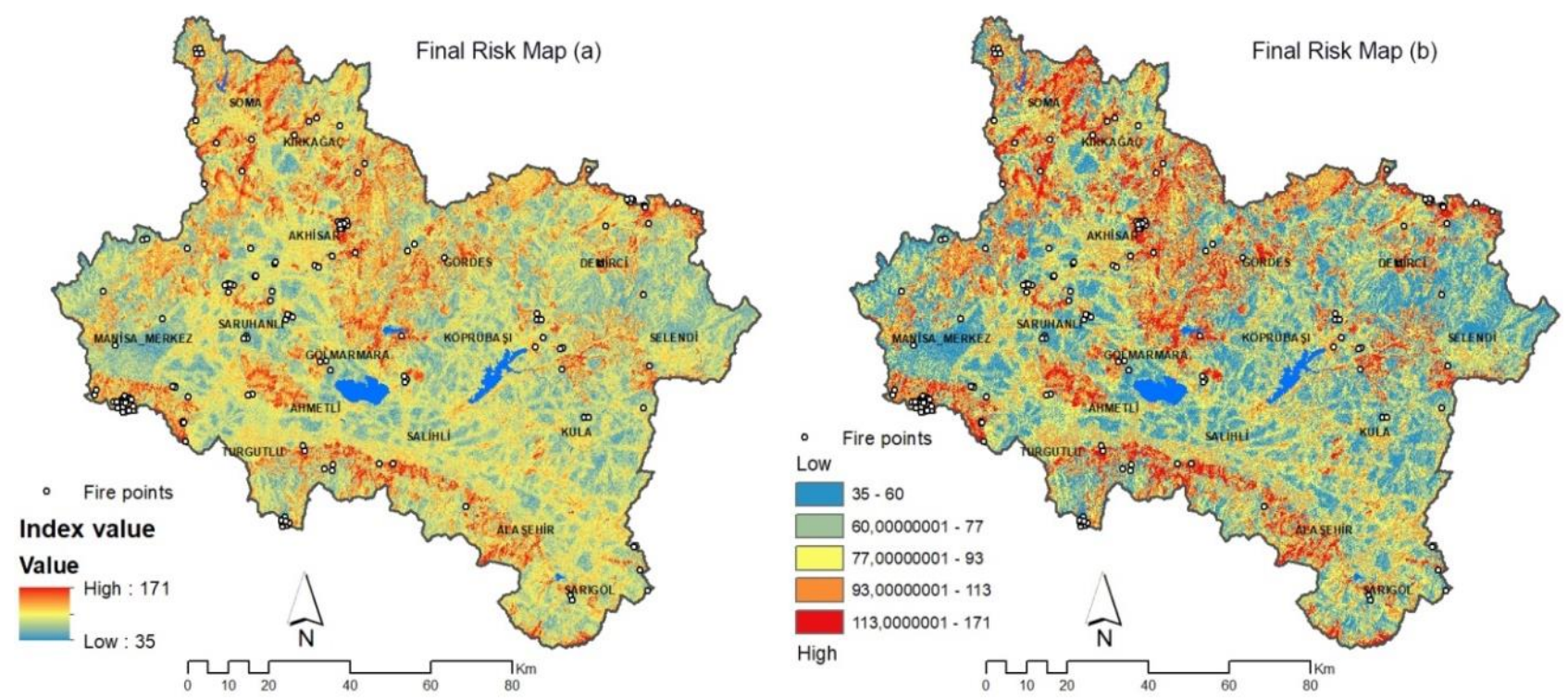

Figure 4. Final fire risk map as (a) continuous data and (b) string data
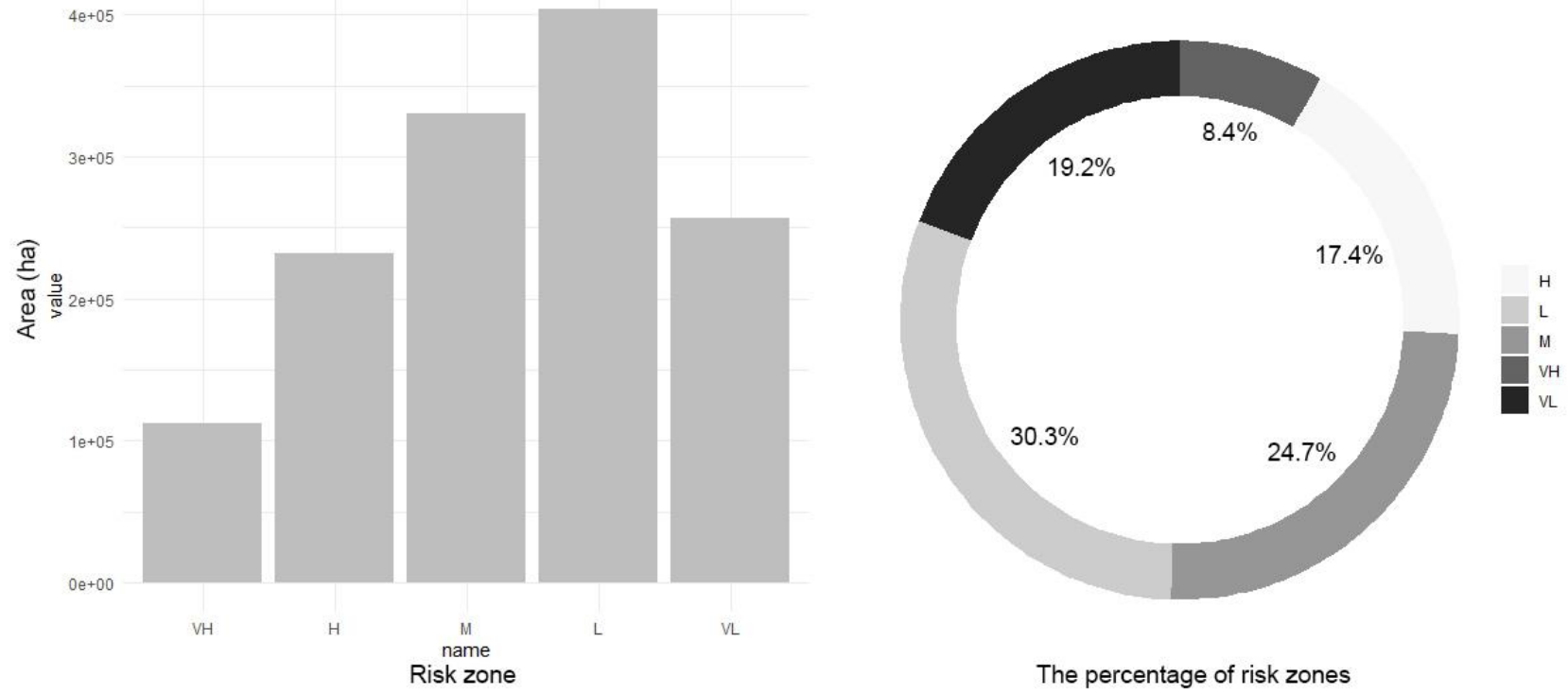

Figure 5. (a) Bar chart displaying differences in the area size of forest fire risk zones, (b) pie chart displaying the percentage of forest fire risk zones (VH: Very high, H: High, M: Medium, L: Low, VL: Very low) 
3.3. Examining the distribution of fire archive records to fire risk zones

Figure 6 shows the distribution of 149 forest fires in the fire archive records from 2001 to 2018 obtained from the MODIS satellite image for Manisa province by years. The years with the highest number of fires are 2007 and 2008, respectively. Twenty fires were recorded in 2007 and 17 in 2008.

149 forest fires in the fire archive records of 2001-2018 obtained from MODIS satellite images were overlapped with very high and high-risk areas and it was concluded that $65.1 \%$ of forest fires broke out in very high and high-risk areas (Figure 7). There is a positive, linear and strong correlation between forest fire points in fire records and areas with very high and high risk. This finding supports the accuracy of the resulting fire risk map.

The areas identified as having very high and high fire risks are located in the northern and north-western parts of the project site with Spil Mountain Natural Park being in the very high risk group. According to the research findings, forest fires occurred most frequently in 2007 and 2008. Additionally, in 2008 forest fire impacts in Manisa and the surrounding area were significantly more severe then were forest fire impacts in neighbouring provinces. Between 2001 and 2018, 348 forest fires were recorded in the Forest Regional Directorates in the Muğla Forest Regional Directorate, 212 in the Antalya Forest Regional Directorate, and 151 in the Izmir Forest Regional Directorate, where Manisa is affiliated (Türkeş and Altan, 2012).

In landscape planning, it is possible to adopt a reliable approach for the prevention and reduction of forest fires by using RS and GIS techniques to analyse spatial variables (Chuvieco and Congalton, 1989). Protecting forest from undesirable fires plays a crucial role in maintaining a sustainable forest ecosystem. Although it is not easy to predict forest fires, the potential damages can be minimized or eliminated using suitable analysis and precautions (Gigović et al., 2018; Colak and Sunar, 2020). The results of the research presented in this paper include important tools for the prevention of forest fires in Manisa, and guidance for all institutions dealing with disaster management and emergency services.

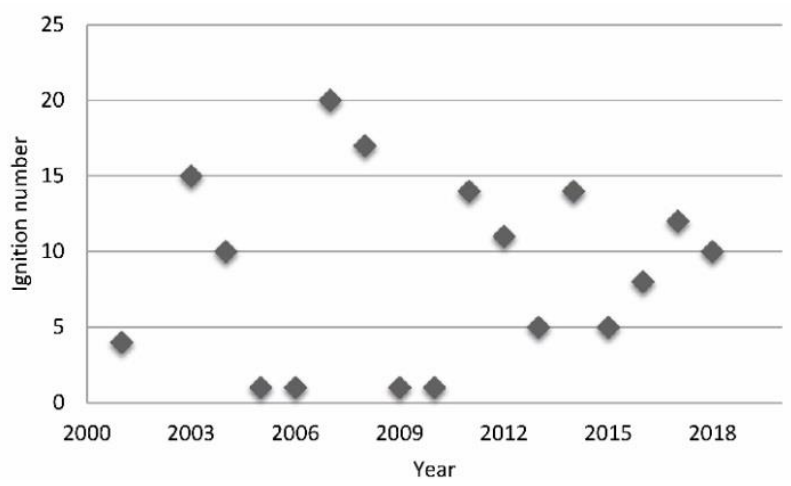

Figure 6. Fire ignition numbers between 2001 and 2018 in Manisa province (a)

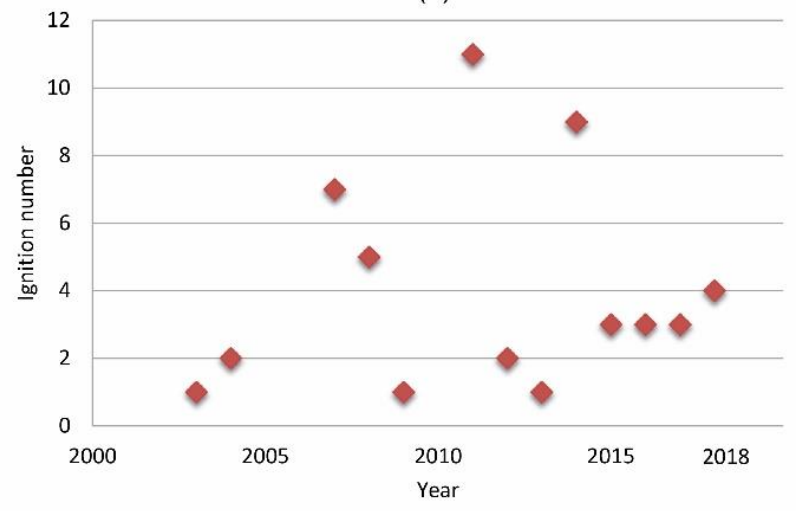

(b)

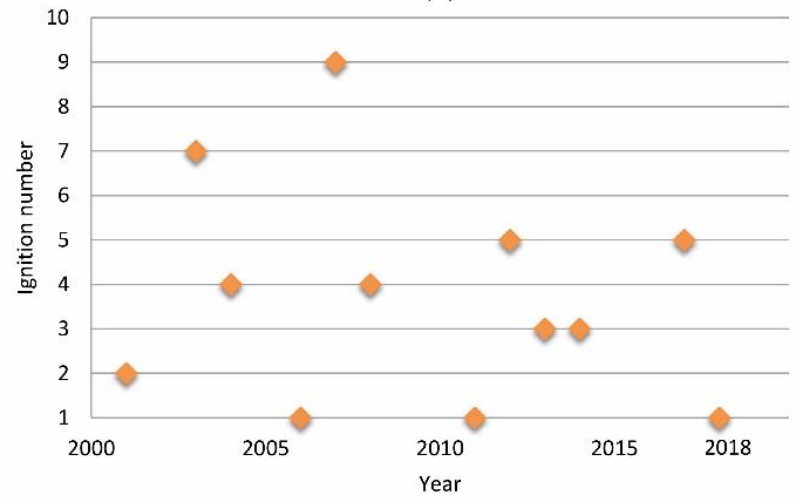

Figure 7. Validation of fire points with (a) very high-risk zone, (b) high-risk zone

The forest fire risk map can help agencies of the General Directorate of Forestry manage forest fire risk sites. The forest fire risk map can make a significant contribution to preventing possible fires and to intervening earlier to reduce forest fire damage (Catry et al., 2010). Determining the degree of risk with RS and GIS techniques can also serve as a basis for environmental monitoring and evaluation studies (Senturk, 2018). The FRZI Model used in this study could be further developed by refining the risk factors and integrating the analysis with other types of multi-criteria analysis. Other RS and GIS techniques such as adaptive filtering (Coban and Ozdamar, 2014) and kernel density (Kuter et al., 2011) can also contribute to forest fire risk modelling especially at the sub-district level. Ignition points could be considered as a dependent variable, while topographic, anthropogenic, and climatic characteristics could be considered independent variables. The weight of the variables utilized in the risk modelling is associated with the technique that used. However some subjectivity in the determination of the weightings is required (Gungoroglu, 2017) regardless of how literature is reviewed, expert views utilized or statistical methods applied. Further the precision of the FRZI model may also be increased by adding additional explanatory variables in the analysis such as climate data. Many researchers have found that climate change occurs gradually and can directly impact length and severity of the forest fires (Kumari and Pandey, 2020). Globally forest fires have many causes of emergence, with climatic drought directly indicating forest fire risk. Therefore, the authors recommend that the FRZI model 
consider the use climate based variables to further improve reliability (Colak and Sunar, 2020). Indices such as Drought Index introduced by the United Nations Convention to Combat Desertification, the Haines index, the KeetchByram drought index, and the Nesterov ignition index have been successful in predicting forest fires. However, in Turkey the records show that most of the forest fires have been caused by people on purpose or accidentally (Bahadır, 2010). This marks the social aspect of forest fires. Studies show that almost $90 \%$ of forest fires in Turkey were human caused, primarily carelessness, neglect, and intent (Avc1 et al., 2009; Bahadır, 2010; Göktepe and Avc1, 2015).

\section{Conclusion}

The aim of this study was to develop a forest fire risk map of Manisa based on a multi-criteria analysis. To develop the forest fire risk map, it was necessary to model the risk factors using the FRZI model. Six risk factors were used: vegetation cover, slope, aspect, elevation, distance to settlement, and distance to road. A limitation of this research is that the weight coefficients assigned in the multicriteria analysis were developed solely through literature review. The application of expert knowledge in the relevant field would further enhance the FRZI model. This research presented in this paper, vegetation cover, slope, aspect, elevation, distance to settlement, and distance to road were used to determine risk zones. Given that the human factor is so important in the occurrence of forest fires in Turkey, the authors recommend a that more detailed examination of the social aspect of forest fires be undertaken The scope of this examination could include public awareness of the need for forest protection, the uses of forests, protection and prevention studies, and the practice of using forest fires to clear land on private property for development purposes. In conclusion, the results of the research show that RS and GIS techniques can be used effectively for estimating forest fire risk and preventing forest fires.

\section{Acknowledgements}

We would like to express our special thanks to Assoc. Prof. Dr. Cumhur Gungoroglu for his guidance to this research paper and sharing his knowledge and experience with us, for his contributions. We also thank the academic staff of Forest Engineering Department of Suleyman Demirel University who organized the scientific activity entitled "Preparing Environmental Databases Using GIS and Satellite Imagery for Natural Ecosystems" (Project No: 1059B291500065), supported by TUBITAK.

\section{References}

Abedi Gheshlaghi, H., Feizizadeh, B., Blaschke, T., 2019. GISbased forest fire risk mapping using the analytical network process and fuzzy logic. Journal of Environmental Planning and Management, 63(3):481-499.

Adab, H., Kanniah, K.D., Solaimani, K., 2013. Modeling forest fire risk in the northeast of Iran using remote sensing and GIS techniques. Natural Hazards, 65(3):1723-1743.

Akkas, M.E., Bucak, C., Boza, Z., Eronat, H., Bekereci, A., Erkan, A., Cebeci, C., 2008. Investigation of Large Forest Fires in the Light of Meteorological Data. Republic of Turkey Ministry of Environment and Forestry, Aegean Forestry Research Institute, 36.
Avc1, M., Korkmaz, M., Alkan, H., 2009. Türkiye'de orman yangınlarının nedenleri üzerine bir değerlendirme. I. Orman Yangınları ile Mücadele Sempozyumu, 07-10 Ocak, Antalya, s. 33-45.

Bahadır, M., 2010. Türkiye'de (1998-2007) Görülen orman yangınlarının yüzey ve rakamsal sorgulama analizi. Nature Sciences, 5(3): 146-162.

Belgherbi, B., Benabdeli, K., Mostefai, K., 2018. Mapping the risk forest fires in Algeria: Application of the forest of Guetarnia in Western Algeria. Ekológia (Bratislava), 37(3): 289-300.

Bingol, B., 2017. Determination of forest fire risk areas in Burdur Province using Geographical Information Systems. Turkish Journal of Forest Science, 1(2):169-182.

Cardille, J.A., Ventura, S.J., 2001. Occurrence of wildfire in the northern Great Lakes Region: effects of land cover and land ownership assessed at multiple scales. International Journal of Wildland Fire, 10(2):145-154.

Catry, F.X., Rego, F.C., Bação, F.L., Moreira, F., 2010. Modeling and mapping wildfire ignition risk in Portugal. International Journal of Wildland Fire, 18(8):921-931.

Chou, Y.H., Minnich, R.A., Chase, R.A., 1993. Mapping probability of fire occurrence in San Jacinto Mountains, California, USA. Environmental Management, 17(1):129-140.

Chuvieco, E., Congalton, R.G., 1989. Application of remote sensing and geographic information systems to forest fire hazard mapping. Remote sensing of Environment, 29(2):147159.

Coban, H.O., Eker, M., 2010. Analysis of forest road network conditions before and after forest fire. $43^{\text {rd }}$ International Symposium on Forestry Mechanisation, July 11-14, Padova Italy, pp. 11-14.

Coban, H.O., Erdin, C., 2020. Forest fire risk assessment using GIS and AHP integration in Bucak forest enterprise, Turkey. Applied Ecology and Environmental Research, 18(1):15671583.

Coban, H.O., Ozdamar, S., 2014. Mapping forest fire in relation to land-cover and topographic characteristics. Journal of Environmental Biology, 35(1): 217.

Colak, E., Sunar, F., 2020. Evaluation of forest fire risk in the Mediterranean Turkish forests: A case study of Menderes region, Izmir. International Journal of Disaster Risk Reduction, 101479.

Díaz-Delgado, R., Lloret, F., Pons, X., 2004. Spatial patterns of fire occurrence in Catalonia, NE, Spain. Landscape Ecology, 19(7):731-745.

Dong, X.U., Li-min, D., Guo-fan, S., Lei, T., Hui, W., 2005. Forest fire risk zone mapping from satellite images and GIS for Baihe Forestry Bureau, Jilin, China. Journal of forestry research, 16(3): 169-174.

Duran, C., 2014. Mersin ilindeki orman yangınlarının başlangıc noktalarına göre mekânsal analizi (2001-2013). Ormancılık Araştırma Dergisi, 1(1): 38-49.

Fischer, A.P., Vance-Borland, K., Jasny, L., Grimm, K. E., Charnley, S., 2016. A network approach to assessing social capacity for landscape planning: The case of fire-prone forests in Oregon, USA. Landscape and Urban Planning, 147:18-27.

GDF, 2017. Activity Report of Strategy Development Department. Republic of Turkey General Directorate of Forestry, Ankara.

Ghobadi, G.J., Gholizadeh, B., Dashliburun, O.M., 2012. Forest fire risk zone mapping from geographic information system in Northern Forests of Iran (Case study, Golestan province). International Journal of Agriculture and Crop Sciences, 4(12): 818-824.

Gigović, L., Jakovljević, G., Sekulović, D., Regodić, M., 2018. GIS Multi-Criteria Analysis for Identifying and Mapping Forest Fire Hazard: Nevesinje, Bosnia and Herzegovina. Tehnički vjesnik, 25(3):891-897.

Göktepe, S., Avcı, M., 2015. Muğla-Fethiye ormanlarında yangın sorunu, yangınların dağılımı ve yangınlar üzerinde etkili olan faktörler. Türkiye Ormancılık Dergisi, 16(2): 130-140. 
Gugliette, D., Conedera, M., Mazzolenıs, S., Ricotta, C., 2011. Mapping fire ignition risk in a complex anthropogenic landscape. Remote Sensing Letters, 2(3):213-219.

Guney, C.O., Ozkan, K., Sentürk, O., 2016. Modelling of spatial prediction of fire ignition risk in the Antalya-Manavgat district. Journal of the Faculty of Forestry Istanbul University, 66(2): 459-470.

Gungoroglu, C., 2017. Determination of forest fire risk with fuzzy analytic hierarchy process and its mapping with the application of GIS: The case of Turkey/Cakırlar. Human and Ecological Risk Assessment, 23(2):388-406.

Hacisalihoglu, M., 2018. Forest fire risk mapping using multi criteria decision analysis method: The case of Karabuk. In Turkish. MSc Dissertation, Zonguldak Bulent Ecevit University, Zonguldak, Turkey.

Jaiswal, R.K., Mukherjee, S., Raju, K.D., Saxena, R., 2002. Forest fire risk zone mapping from satellite imagery and GIS. International Journal of Applied Earth Observation and Geoinformation, 4(1): 1-10.

Joaquim, G.S., Bahaaeddin, A., Josep, R.C., 2007. Remote Sensing Analysis to Detect Fire Risk Locations. Proceedings of GéoCongrès, 2-5 October, Québec, Canada.

Karabulut, M., Karakoc, A., Gurbuz, M., Kizilelma, Y., 2013. Determination of forest fire risk areas using geographical information systems in Baskonus Mountain (Kahramanmaras). The Journal of International Social Research, 6(24):171-179.

Keifer, M., Caprio, E.A., Lineback, P., 2000. Incorporating a GIS model of ecological need into fire management planning. Joint Fire Sciences Conference and Workshop, 15-17 June, Idaho, USA.

Kumari, B., Pandey, A.C., 2020. MODIS based forest fire hotspot analysis and its relationship with climatic variables. Spatial Information Research, 28(1): 87-99.

Kuter, S., Usul, N., Kuter, N., 2011. Bandwidth determination for kernel density analysis of wildfire events at forest sub-district scale. Ecological Modelling, 222(17): 3033-3040.

Lin, J., Sergio, R., 2009. A derivation of the statistical characteristics of forest fires. Ecological Modelling, 220:898903.

Malczewski, J., 1999. GIS and Multicriteria Decision Analysis. ISBN: 0-471-32944-4, John Wiley and Sons, New York.

Malik, T., Rabbani, G., Farooq, M., 2013. Forest fire risk zonation using remote sensing and GIS technology in Kansrao Forest Range of Rajaji National Park, Uttarakhand, India. India. International Journal of Advanced RS and GIS, 2(1):86-95.
Martínez-Fernández, J., Chuvieco, E., Koutsias, N., 2013. Modelling long-term fire occurrence factors in Spain by accounting for local variations with geographically weighted regression. Natural Hazards and Earth System Sciences, 13(2):311-327.

MOI, 2019. E-Interior Project. Ministry of Interior, Ankara.

MOM, 2019. Geography of Manisa. Information Processing Department of Manisa Municipality, Manisa.

MPCTD, 2019. General Information, Manisa Provincial Culture and Tourism Directorate, Geography of Manisa.

Neyisci, T., 1987. A Study on Slow-Burning Plant Species for Preventing Forest Fires. Tubitak Journal of Nature, 11: 595604.

Nuthammachot, N., Stratoulias, D., 2019. A GIS-and AHP-based approach to map fire risk: A case study of Kuan Kreng peat swamp forest, Thailand. Geocarto International, 1-14.

Pradhan, B., Dini Hairi Bin Suliman, M., Arshad Bin Awang, M., 2007. Forest fire susceptibility and risk mapping using remote sensing and geographical information systems (GIS). Disaster Prevention and Management: An International Journal, 16(3):344-352.

Renard, Q., Pélissier, R., Ramesh, B.R., Kodandapani, N., 2012. Environmental susceptibility model for predicting forest fire occurrence in the Western Ghats of India. International Journal of Wildland Fire, 21(4): 368-379.

Roy, P.S., 2003. Forest fire and degradation assessment using satellite remote sensing and geographic information system. Satellite Remote Sensing and GIS Applications in Agricultural Meteorology, 361-400.

Senturk, N., 2018. Assessment of relationship between locations and distances to roadside of forest fires in Istanbul, Turkey. Applied Ecology and Environmental Research, 16(5): 61956204.

Sowmya, S.V., Somashekar, R.K., 2010. Application of remote sensing and geographical information system in mapping forest fire risk zone at Bhadra wildlife sanctuary, India. Journal of Environmental Biology, 31(6): 969

Tian, X., Zhao, F., Shu, L., Wang, M., 2013. Distribution characteristics and the influence factors of forest fires in China. Forest Ecology and Management, 310:460-467.

Türkeş, M., Altan, G., 2012. Analysis of the year 2008 fires in the forest lands of the Muğla Regional Forest Service by using drought indices. Journal of Human Sciences, 9(1): 912-931.

Yang, J., He, H.S., Shifley, S.R., Gustafson, E.J., 2007. Spatial patterns of modern period human-caused fire occurrence in the Missouri Ozark Highlands. Forest science, 53(1): 1-15. 